\title{
Physiochemical, Biochemical, Minerals Content Analysis, and Antioxidant Potential of National and International Honeys in Pakistan
}

\author{
Mahmood Ahmed, ${ }^{1}$ Muhammad Imtiaz Shafiq, ${ }^{2}$ Anum Khaleeq, ${ }^{3}$ Rahila Huma, \\ Muhammad Abdul Qadir, ${ }^{1}$ Ayesha Khalid, ${ }^{3}$ Amir Ali, ${ }^{1}$ and Abdul Samad ${ }^{1}$ \\ ${ }^{1}$ Institute of Chemistry, University of Punjab, Lahore 54590, Pakistan \\ ${ }^{2}$ Institute of Biochemistry and Biotechnology, University of the Punjab, Lahore 54590, Pakistan \\ ${ }^{3}$ Government Kinnaird College, Lahore 54500, Pakistan \\ Correspondence should be addressed to Muhammad Imtiaz Shafiq; imtiazshafiqm@yahoo.com
}

Received 4 January 2016; Accepted 14 February 2016

Academic Editor: Kamlesh Shrivas

Copyright (C) 2016 Mahmood Ahmed et al. This is an open access article distributed under the Creative Commons Attribution License, which permits unrestricted use, distribution, and reproduction in any medium, provided the original work is properly cited.

\begin{abstract}
16 honey samples from Pakistan and two other countries were investigated for their physiochemical, biochemical, minerals, and antioxidant potential. Antioxidant activities of all honey samples were performed by using percentage inhibition of DPPH free radical, AEAC, and FRAP. 5-HMF and mineral contents were determined by HPLC and AAS, respectively. The obtained values of respective parameters, namely, $\mathrm{pH}, \mathrm{EC}$, TDS, total acidity, moisture, ash, color intensity, sugars, proline, and protein were in compliance with codex standard and recommendation of council directive by European Union. The total phenolics contents in acacia honey from Germany and jujube honey from Pakistan are similar to monofloral honey from Saudi Arabia and Yemen, respectively. The mineral contents in tested honey samples are comparable with honey from Brazil and Romania. Dark color honeys contained higher phenolic contents than light color ones and attributed to higher oxidation potential and have strong positive correlation with DPPH and FRAP.
\end{abstract}

\section{Introduction}

Honey is complex supersaturated sweet natural liquid produced by honeybees from the nectar of plants. The substances collected by bees then after combined with their own specific substances are deposited, dehydrated, stored, and left in honeycombs to ripen and mature. Around 200 substances have been reported in this complex natural liquid but the composition especially its secondary metabolites and quality of honey may be influenced by some external factors such as environmental and seasonal factors, processing, handling, and storage [1-3]. The substances included in honey are sugars (main components: fructose $38 \%$, glucose $31 \%$ ), proteins, moisture (10-20\%), vitamins (ascorbic acid, niacin, etc.), mineral salts (potassium, calcium, sodium, phosphorus, etc.), organic acids (acetic acid and gluconic acid, etc.), 5-hydroxymethylfurfural (HMF), enzymes (phosphatases, glucose oxidase, invertase, and catalase), flavonoids, phenolic acids, and volatile compounds. EC Directive 2001/110 specified the criteria to ensure the quality of honey by contents analysis, namely, electrical conductivity, moisture, ash, free acidity, sugars (reducing and nonreducing), HMF, and diastase activity [4-6]. As natural antioxidant and having high nutritional values, honey has been consumed over the years by humanity. Many enzymes like glucose oxidase, catalase, and peroxidase and nonenzymes, namely, carotenoids, $\alpha$ tocopherol, vitamin C, proteins, amino acids, flavonoids, polyphenols, Maillard reaction products, and small amount of mineral content, particularly iron and copper, are responsible for the redox properties of honey. Flavonoids present in honey comprising of flavanones, flavones, and flavonols while phenolic acids are substituted cinnamic acids and benzoic acids and these compounds are main contributor for color, taste, and aroma of honey [7-10]. A strong correlation 
between phenolic contents especially the total phenolic contents and antioxidant activities of honey from different region of world has been reported. The dark colored honey has higher phenolic contents consequently which indicate the higher antioxidative properties [11-13]. Antioxidant is prominent characteristics of honey but it also possesses various other biological activities like wound healing and antiinflammatory, antimicrobial activities as well as in the treatment of gastrointestinal disorders and skin diseases [14-17]. Since the antioxidant power of honey is strongly correlated with its phenolic contents, its therapeutic potential is associated with its antioxidant capacity against reactive oxygen species produced in physiological and metabolic processes. Antioxidants reduce the risk of chronic disease emerged as a result of oxidative damage such as cancer, heart disease, and neurological degeneration [18]. These degenerative diseases are initiated by the oxidative mechanism of free radicals like peroxides, hydrogen peroxide, and lipid peroxyl so polyphenols, flavonoids, and phenolic acids present in honey scavenge these free radicals to oxidize the proteins, nucleic acids, and lipids and inhibit the degenerative diseases [19]. From different region of world, it has been reported that honey has capacity to prevent inflammatory disease associated with lipid peroxidation and reduce oxidative damage of erythrocytes. Honeys are more potent antioxidant than vitamins A, $\mathrm{C}$, and $\mathrm{E}$ and reduce the immune response causing inflammation [20-22]. To the best of our knowledge, this is first study established in Pakistan for physiochemical $(\mathrm{pH}$, electrical conductivity, acidity, total dissolved solids, moisture, color, ash, 5-hydroxymethylfurfural (HMF) concentrations, and color intensity), biochemical (sugars, total phenolics and flavonoids, protein, ascorbic acid, and proline contents), mineral contents ( $\mathrm{Ca}, \mathrm{Cd}, \mathrm{Co}, \mathrm{Cr}, \mathrm{Cu}, \mathrm{Fe}, \mathrm{K}, \mathrm{Mg}, \mathrm{Mn}, \mathrm{Na}$, $\mathrm{Ni}, \mathrm{Pb}$, and $\mathrm{Zn}$ ), and antioxidant activities such as AEAC (ascorbic acid equivalent antioxidant content), scavenging activity of DPPH (1,1-diphenyl-2-picrylhydrazyl) free radical, and FRAP (ferric reducing antioxidant power) of honey available in a second largest city (Lahore) of the country.

\section{Materials and Methods}

2.1. Honey Samples. Sixteen honey samples were collected from local market shelves in the capital city Lahore, PunjabPakistan. Each sample was of $250 \mathrm{~g}$ packed in glass bottle, and none of samples exceeded the storage period of three months. All the samples were stored at $4^{\circ} \mathrm{C}$ and before analysis kept overnight at $25 \pm 2^{\circ} \mathrm{C}$. Among the tested honey samples twelve samples were of Pakistani honey coded as PAKH-1-PAKH-12, two samples each of German honey coded GERH-13, GERH-14, and French honey coded FRNH15, FRNH-16. The PAKH-11 and GERH-13 are monofloral as jujube and acacia, respectively, while remaining were multifloral.

\subsection{Physiochemical Analysis}

2.2.1. $\mathrm{pH}$, Acidity, Electrical Conductivity (EC), and Total Dissolved Solids (TDS). A 10\% (w/v) honey solution was prepared in high purity water $(0.01 \mu \mathrm{S} / \mathrm{cm})$ using purification system (Milli-Q, USA) and $\mathrm{pH}$ was determined by multimeter (Orion 5 star, Thermo Scientific, UK). 0.05 M sodium hydroxide (Merck, Germany) was used for free acidity by plotting the neutralization curve while for lactone acidity, excess sodium hydroxide was added to honey solution and back titrated with $0.025 \mathrm{M}$ sulphuric acid (Merck, Germany). Summation of both free and lactone acidity is equivalent to total acidity. TDS in ppm and $\mathrm{EC}$ in $\mathrm{mS} / \mathrm{cm}$ were measured by Orion 5 star multimeter (Thermo Scientific, UK). $20 \mathrm{~g}$ honeys were suspended in $75 \mathrm{~mL}$ of high purity water in volumetric flask and make the volume up to $100 \mathrm{~mL}$ with same solvent.

2.2.2. Moisture, Ash Contents, Color, and Its Intensity. Refractive index measurement method by Wedmore's formula [23] was used and the moisture was expressed in percentage. Ash dish was heated at the ashing temperature and then $5.0 \mathrm{~g}$ of honey is placed along with two drops of ash-free olive oil. We placed the ash dish in furnace (Thermolyne ${ }^{\mathrm{TM}}$, Thermo Scientific UK) and commenced ashing without loss at a low heat rising to $350-400^{\circ} \mathrm{C}$. The ash dish is cooled at room temperature and ash content was calculated as $\mathrm{g}$ ash per $100 \mathrm{~g}$ of honey [24]. The color of honey was categorized by Pfund scale after changing an absorbance value. Color grades were expressed in millimeter $(\mathrm{mm})$ Pfund grades using glycerol (Sigma Aldrich, USA) as reference standard for comparison. PG-T80 ${ }^{+} \mathrm{UV}-\mathrm{Vis}$ spectrophotometer, UK, was used to measure the absorption at $635 \mathrm{~nm}$. In warm high pure water $50 \%(\mathrm{w} / \mathrm{v})$ of honey solution was made and then filtered using a nylon $0.45 \mu \mathrm{m}$ filter. The absorption was measured by using spectrophotometer at 450 and $720 \mathrm{~nm}$. Differences of absorbance were stated is $\mathrm{mAU}[25]$.

2.2.3. 5-Hydroxymethylfurfural (HMF) Concentration. 5-Hydroxymethylfurfural (Sigma Aldrich, USA) concentration was determined by slight modification in reported method [26]. For stock solution, $1.0 \mathrm{~g}$ 5-hydroxymethylfurfural was dissolved in water and make volume up to $1000 \mathrm{~mL}$; 0$80 \mathrm{mg} / \mathrm{kg}$ standard solutions for linearity were prepared by dissolving the respective volumes in mobile phase water (Milli-Q) and methanol (Thermo Scientific, UK) $(90: 10)$ from stock solution. The chromatography was performed on Mediterranean $^{\mathrm{TM}}$ sea $18(5 \mu \mathrm{m}, 4.6 \times 250 \mathrm{~mm})$ column at room temperature $\left(25 \pm 2^{\circ} \mathrm{C}\right)$ under optimized experimental conditions. $1.0 \mathrm{~mL} / \mathrm{min}$ flow rate was adjusted by injecting the volume of $20 \mu \mathrm{L}$ using Rheodyne sample injection port. The separation was performed on HPLC system (Shimadzu, Kyoto-Japan) equipped with degasser (DGU-4A), pump (LC20AD), column oven (CTO-20A), and UV-Visible detector (SPD20A) and detection was performed at $285 \mathrm{~nm}$. Each test required just $5 \mathrm{~min}$. and before injection all the standards, sample solutions, and mobile phase were filtered through membrane filter of $0.45 \mu \mathrm{m}$ and then sonicated. Peak areas integration was done by Shimadzu LC solution software (version 1.227). All the reagents used were of HPLC grade. The results of 5 -HMF are expressed in $\mathrm{mg} / \mathrm{kg}$ of honey. 


\subsection{Biochemical Analysis}

2.3.1. Sucrose, Reducing Sugar, and Total Sugar. $1.0 \mathrm{~mL}$ of $1.0 \mathrm{mg} / \mathrm{mL}$ of honey solution in water was mixed with $1.0 \mathrm{~mL}$ of 3,5-dinitrosalicylic acid (DNSA) (Sigma Aldrich, USA), the solution was warmed in water bath for ten minutes, and the absorption of resulting reddish-orange color was measured spectrophotometrically at $540 \mathrm{~nm}$. The glucose (Merck, Germany) was used as reference standard. Sucrose content in each honey sample was measured by refractometric method using 20\% (w/v) solution. Sum of concentration of reducing sugar and sucrose results in the total sugar contents in $\mathrm{g} / 100 \mathrm{~g}$ of honey [2].

2.3.2. Total Phenolics and Flavonoids. Folin-Denis method was used for determination of total phenolics in honey. Standard solutions of gallic acid (Sigma Aldrich, USA) (0$200 \mu \mathrm{g} / \mathrm{mL}$ ) were used for calibration curve. The total phenol content was expressed as milligrams of gallic acid equivalents (mg GAE)/kg of honey. $2.0 \mathrm{~mL}$ of honey solution $(2.0 \mathrm{mg} / \mathrm{mL}$ in methanol) was mixed with $2.0 \mathrm{~mL}$ of $2 \%$ methanolic solution of aluminum trichloride (Sigma Aldrich, USA). The solution mixer was incubated for $30 \mathrm{~min}$. at room temperature and the absorption was measured at $415 \mathrm{~nm}$ against methanol (Sigma Aldrich, USA) as blank reagent. Standard solutions of quercetin (Sigma Aldrich, USA) $(0-200 \mu \mathrm{g} / \mathrm{mL}$ ) were used for calibration curve. The total flavonoids content was expressed as milligrams of quercetin equivalents (mg QE)/kg of honey [27].

\subsubsection{Total Protein, Proline, and Ascorbic Acid Content.} Protein contents were determined by Folin-Denis reagent method [28] and results of protein in honey samples are presented in $\mathrm{mg} / \mathrm{g}$ of honey. For proline, $0.5 \mathrm{~mL}$ of honey solution $(5.0 \mathrm{~g} / 100 \mathrm{~mL}$ of water) was added in test tube, mixed with $1.0 \mathrm{~mL}$ of formic acid (Sigma, Aldrich, USA) and $1.0 \mathrm{~mL}$ of 3\% Ninhydrin (Sigma, Aldrich, USA) in ethylene glycol monomethylether (Fisher Scientific, UK), and shaken vigorously for $15 \mathrm{~min}$. The test tube was placed in water bath (TW8 Julabo, Germany) at $70^{\circ} \mathrm{C}$ for $10 \mathrm{~min}$ and then $5.0 \mathrm{~mL}$ of $50 \%$ propanol (Fisher Scientific, UK) solution was added in water. The test tube was cooled at temperature and the absorption was measured at $510 \mathrm{~nm}$. Same procedure was adopted for reagent blank water and reference standard of $0.8 \mathrm{mg} / 25 \mathrm{~mL}$ of proline (Sigma, Aldrich, USA) [29]. The results of proline contents in honey samples are expressed in $\mathrm{mg} / \mathrm{kg}$ of honey. $100 \mathrm{mg}$ of honey sample was extracted with $10 \mathrm{~mL}$ of $1 \%$ metaphosphoric acid (Sigma, Aldrich, USA) at room temperature for $45 \mathrm{~min}$ and filtered through filter paper (Whatman number 4). $9.0 \mathrm{~mL}$ of $0.005 \%$ 2,6-dichlorophenolindophenol (Sigma, Aldrich, USA) was mixed with $1.0 \mathrm{~mL}$ of filtrate and absorption was measured at $515 \mathrm{~nm}$ within $30 \mathrm{~min}$. Ascorbic acid (Sigma Aldrich, USA) in concentration range of $50-400 \mu \mathrm{g} / \mathrm{mL}$ was used for calibration curve [9]. The results of ascorbic acid contents in honey samples are presented in $\mathrm{mg} / \mathrm{kg}$ of honey.

\subsection{Antioxidant Activities}

2.4.1. Ascorbic Acid Equivalent Antioxidant Content (AEAC). A $0.75 \mathrm{~mL}$ of methanolic honey solution $(0.03 \mathrm{~g} / \mathrm{mL})$ was mixed with 2,2-diphenyl-1-picrylhydrazyl (Sigma, Aldrich, USA) $(0.02 \mathrm{mg} / \mathrm{mL}$ in methanol). The mixture was incubated at room temperature for $15 \mathrm{~min}$. and the absorption was measured at $517 \mathrm{~nm}$. Ascorbic acid in concentration range of $1-8 \mu \mathrm{g} / \mathrm{mL}$ was used for calibration curve [10]. Antioxidant activity was expressed as milligrams of ascorbic acid equivalent antioxidant content (mg AEAC)/100 g of honey.

\subsubsection{1, 1-Diphenyl-2-Picrylhydrazyl (DPPH) Activity. DPPH} free radical scavenging activity of honey was determined as reported earlier [30], methanolic DPPH $(0.024 \mathrm{mg} / \mathrm{mL}$, $2.7 \mathrm{~mL})$ was mixed with $0.5 \mathrm{~mL}(0.2 \mathrm{~g} / \mathrm{mL})$ of honey extract, and the mixture was shaken vigorously and left at room temperature for $30 \mathrm{~min}$. in dark. DPPH radical scavenging effect was determined by measuring the absorption at $517 \mathrm{~nm}$. The percentage scavenging activity of $\mathrm{DPPH}$ radical was calculated as follows: \% RSA $=\left(\left[A_{\mathrm{DPPH}}-A_{S}\right] / A_{\mathrm{DPPH}}\right) \times$ 100 , where $A_{S}$ is the absorbance of sample solution and $A_{\mathrm{DPPH}}$ is the absorbance of the DPPH solution. Butylated hydroxytoluene (BHT) was used as a reference standard.

2.4.3. Ferric Reducing Antioxidant Power (FRAP) Assay. FRAP assay was performed to reduce the $\mathrm{Fe}^{3+}$-TPTZ complex (yellow) to $\mathrm{Fe}^{2+}-\mathrm{TPTZ}$ (blue). FRAP reagent was prepared by mixing $0.3 \mathrm{M}$ acetate buffer ( $\mathrm{pH} 3.6$ ), 0.010 M 2,4,6tripyridyl-S-triazine (TPTZ) (Sigma, Aldrich, USA) solution in $0.040 \mathrm{M} \mathrm{HCl}$ (Merck, Germany), and $0.020 \mathrm{M} \mathrm{FeCl}_{3} \cdot 6 \mathrm{H}_{2} \mathrm{O}$ (Merck, Germany) in ratio of $10: 1: 1.1 .5 \mathrm{~mL}$ of FRAP reagent was mixed in $0.2 \mathrm{~mL}$ of honey solution $(0.1 \mathrm{~g} / \mathrm{mL})$ and incubated for $4 \mathrm{~min}$ at $37^{\circ} \mathrm{C}$ and the absorption was measured at $593 \mathrm{~nm}$ against a reagent blank containing high pure water. Ferrous sulfate (Sigma Aldrich, USA) in concentration range of $100-1000 \mu \mathrm{m} / \mathrm{L}$ was used for calibration curve and FRAP values were expressed as micromoles of ferrous equivalent ( $\mu \mathrm{M}$ Fe [II]) per $100 \mathrm{~g}$ of honey [31].

2.5. Mineral Contents. Digest $1.0 \mathrm{~g}$ of honey in $9.0 \mathrm{~mL} 65 \%$ $\mathrm{HNO}_{3}$ (Merck, Germany) and $1.0 \mathrm{~mL} 30 \% \mathrm{H}_{2} \mathrm{O}_{2}$ (Merck, Germany). Microwave oven (W-1900 Continuous System 220-240 V, Thomas Scientific, USA) was used for digestion procedure. Elemental standard solution each of $\mathrm{Ca}, \mathrm{Cd}, \mathrm{Co}$, $\mathrm{Cr}, \mathrm{Cu}, \mathrm{Fe}, \mathrm{K}, \mathrm{Mg}, \mathrm{Mn}, \mathrm{Na}, \mathrm{Ni}, \mathrm{Pb}$, and $\mathrm{Zn}$ was prepared from stock solution (1000 mg/L) (Fisher Scientific, UK). High pure water was used for diluting solutions. PG-990 atomic absorption spectrometer was used for mineral contents under the optimized instrumental conditions $[32,33]$.

2.6. Statistical Analysis. Statistical analysis was performed on SPSS version 15 (SPSS Inc., Chicago, IL, USA) for windows and analysis of variance (ANOVA) was performed for significant difference using post hoc test $(p<0.05)$. Correlation among the different parameters was established by Pearson's correlation coefficient $(r)$ in bivariate linear correlations 
TABLE 1: pH, TDS, EC, moisture, free acidity, lactone acidity, and total acidity of honey samples (mean $\pm \mathrm{SD}, n=3$ ).

\begin{tabular}{|c|c|c|c|c|c|c|c|}
\hline Code name & $\mathrm{pH}$ & TDS (ppm) & $\mathrm{EC}(\mathrm{mS} / \mathrm{cm})$ & Moisture (\%) & $\begin{array}{c}\text { Free acidity } \\
(\mathrm{meq} / \mathrm{kg})\end{array}$ & $\begin{array}{c}\text { Lactone acidity } \\
(\mathrm{meq} / \mathrm{kg})\end{array}$ & $\begin{array}{c}\text { Total acidity } \\
(\mathrm{meq} / \mathrm{kg})\end{array}$ \\
\hline PAKH-1 & $4.01 \pm 0.01$ & $315.2 \pm 0.91$ & $0.493 \pm 0.008$ & $17.1 \pm 0.12$ & $17.1 \pm 0.12$ & $11.1 \pm 0.11$ & $28.2 \pm 0.48$ \\
\hline PAKH-2 & $3.84 \pm 0.00$ & $250.4 \pm 0.81$ & $0.391 \pm 0.009$ & $12.5 \pm 0.23$ & $33.7 \pm 0.09$ & $3.4 \pm 0.12$ & $37.1 \pm 0.63$ \\
\hline PAKH-3 & $4.17 \pm 0.02$ & $435.8 \pm 0.33$ & $0.681 \pm 0.034$ & $14.3 \pm 0.13$ & $12.3 \pm 0.11$ & $12.1 \pm 0.32$ & $24.2 \pm 0.41$ \\
\hline PAKH-4 & $3.88 \pm 0.01$ & $450.2 \pm 0.31$ & $0.703 \pm 0.072$ & $16.1 \pm 0.11$ & $19.6 \pm 0.21$ & $7.9 \pm 0.33$ & $27.5 \pm 0.33$ \\
\hline PAKH-5 & $3.93 \pm 0.02$ & $302.2 \pm 0.55$ & $0.472 \pm 0.007$ & $14.2 \pm 0.21$ & $21.7 \pm 0.92$ & $8.2 \pm 0.84$ & $29.9 \pm 0.78$ \\
\hline PAKH-6 & $3.97 \pm 0.00$ & $365.1 \pm 0.43$ & $0.571 \pm 0.005$ & $10.1 \pm 0.33$ & $25.6 \pm 0.32$ & $9.5 \pm 0.33$ & $35.1 \pm 0.91$ \\
\hline РAКН-7 & $4.11 \pm 0.01$ & $347.7 \pm 0.52$ & $0.544 \pm 0.011$ & $13.8 \pm 0.14$ & $24.6 \pm 0.21$ & $9.8 \pm 0.32$ & $34.4 \pm 0.53$ \\
\hline PAKH-8 & $3.93 \pm 0.02$ & $295.4 \pm 0.23$ & $0.462 \pm 0.001$ & $17.4 \pm 0.21$ & $17.8 \pm 0.11$ & $11.6 \pm 0.42$ & $29.4 \pm 0.31$ \\
\hline PAKH-9 & $3.84 \pm 0.01$ & $278.3 \pm 0.22$ & $0.435 \pm 0.003$ & $16.5 \pm 0.16$ & $33.7 \pm 0.22$ & $3.4 \pm 0.33$ & $37.1 \pm 0.53$ \\
\hline PAKH-10 & $4.07 \pm 0.02$ & $395.5 \pm 0.54$ & $0.618 \pm 0.006$ & $17.3 \pm 0.21$ & $12.3 \pm 0.31$ & $12.1 \pm 0.43$ & $24.4 \pm 0.44$ \\
\hline PAKH-11 & $4.28 \pm 0.00$ & $378.3 \pm 0.55$ & $0.591 \pm 0.007$ & $16.8 \pm 0.25$ & $17.6 \pm 0.42$ & $3.2 \pm 0.33$ & $20.8 \pm 0.61$ \\
\hline PAKH-12 & $3.83 \pm 0.01$ & $332.3 \pm 0.76$ & $0.519 \pm 0.098$ & $14.7 \pm 0.17$ & $21.3 \pm 0.25$ & $8.1 \pm 0.24$ & $29.4 \pm 0.43$ \\
\hline GERH-13 & $4.21 \pm 0.01$ & $315.2 \pm 0.77$ & $0.493 \pm 0.001$ & $12.1 \pm 0.31$ & $125.6 \pm 0.43$ & $9.5 \pm 0.43$ & $135.1 \pm 0.57$ \\
\hline GERH-14 & $3.84 \pm 0.01$ & $327.2 \pm 0.34$ & $0.511 \pm 0.041$ & $18.8 \pm 0.22$ & $24.6 \pm 0.22$ & $9.8 \pm 0.33$ & $34.4 \pm 0.73$ \\
\hline FRNH-15 & $4.11 \pm 0.02$ & $325.1 \pm 0.33$ & $0.508 \pm 0.001$ & $19.2 \pm 0.31$ & $17.1 \pm 0.87$ & $11.1 \pm 0.44$ & $28.2 \pm 0.64$ \\
\hline FRNH-16 & $3.97 \pm 0.02$ & $281.2 \pm 0.87$ & $0.439 \pm 0.002$ & $15.5 \pm 0.15$ & $32.6 \pm 0.83$ & $3.3 \pm 0.45$ & $35.9 \pm 0.52$ \\
\hline
\end{tabular}

$(p<0.01)$. All the assays were performed in triplicate and results expressed in mean $\pm \mathrm{SD}$.

\section{Results and Discussion}

3.1. Physiochemical Analysis. Acidic $\mathrm{pH}$ is characteristic of honey; the $\mathrm{pH}$ value (Table 1) of twelve Pakistani and four exotic tested honey samples was found to be between 3.83 and 4.28 while free acidity of multifloral honey was between 12.3 and $33.7 \mathrm{meq} / \mathrm{kg}$ and the lactone acidity was observed between 3.4 and $12.1 \mathrm{meq} / \mathrm{kg}$ which are comparable with already reported values in different region of world. Free and lactone acidity value for acacia honey (Monofloral-Germany) was obtained at 125.6 and $9.5 \mathrm{meq} / \mathrm{kg}$ which is comparable with monofloral acacia honey from Saudi Arabia (free acidity: $122.3 \mathrm{meq} / \mathrm{kg}$; lactone acidity: $9.5 \mathrm{meq} / \mathrm{kg}$ ). Jujube honey from Pakistan (Monofloral) has free and lactone acidity value 19.6 and $2.9 \mathrm{meq} / \mathrm{kg}$, respectively, which is similar to honey of same flora from Yemen (free acidity: $17.0 \mathrm{meq} / \mathrm{kg}$; lactone acidity: $3.5 \mathrm{meq} / \mathrm{kg}$ ). The total acidity (Table 1 ) values ranging between 24.2 and $37.1 \mathrm{meq} / \mathrm{kg}$ except the acacia honey (GERH-13: $135.1 \mathrm{meq} / \mathrm{kg}$ ) and these values in compliance with international standard $(50 \mathrm{meq} / \mathrm{kg})$. The acidic $\mathrm{pH}$ of honey is irrespective of its geographical region, but due to presence of organic acids formed after the fermentation of sugars and inorganic anions, for example, phosphates, sulfates. These organic acids are contributor of flavor, acidic $\mathrm{pH}$ of honey which stabilize it and prevent it from bacterial growth because these grow in neutral to slightly alkaline media. Blossom honeys (lower $\mathrm{pH}$ ) and honeydew (higher $\mathrm{pH}$ ) can be distinguished by the $\mathrm{pH}$ values [34]. TDS and EC are interlinked with each other and important parameters to determine the physical characteristics of honey. TDS were between 250 and $450 \mathrm{ppm}$ and EC of tested honey was between the ranges of 0.391 and $0.703 \mathrm{mS} / \mathrm{cm}$ (Table 2) which is lower than the recommended value of $0.8 \mathrm{mS} / \mathrm{cm}$ given by the European Commission [9]. TDS is a measure of all the inorganic and organic substance present in honey either in molecular or in ionized form. Our study indicated the good correlation between TDS and EC; these two parameters can be used to determine the honey purity. The moisture content (Table 1) in Pakistani honey was ranged between 10.1 and $17.3 \%$ while $12.1-19.2 \%$ water content was found in exotic honey. The lower level of water content attributed to dry weather in area of honey production. The moisture content in tested honey samples was in range of codex standard $(\leq 20 \%)$. The moisture present in honey stabilizes and prevents it from fermentation and granulation. Various beekeeping organizations in Germany, Belgium, Austria, Italy, and Switzerland recommended the moisture content maximum $18-18.5 \%$. The moisture content has important role in shelf life of honey, lower the moisture content longer will be shelf life because it prevent the fermentation of osmotolerant yeast. PAKH-2 and PAKH- 6 have the moisture content of $12.5 \%$ and $10.1 \%$, respectively, so it might be attributed for its long shelf life and its ability to be stored for long time. The ash contents were between 0.04 and $0.11 \%$ (Table 2), since the ash content determination has been omitted from standard and replaced by TDS and EC measurement [34-36]. Color is an important characteristic of honey and varied from region to region. Naturally different tones of honey available like light yellow to amber, dark amber, black, and so forth and sometimes reddish and green hue may be present. The colors of honey are classified according to USDA based on the mm Pfund values; the values less than 8 are classified as white, extra white (9$17 \mathrm{~mm})$, white $(18-34 \mathrm{~mm})$, extra light amber $(35-50 \mathrm{~mm})$, light amber (51-85 $\mathrm{mm})$, amber ( $86-114 \mathrm{~mm})$, and more than $114 \mathrm{~mm}$ is characterized as dark amber [34]. Among the tested 


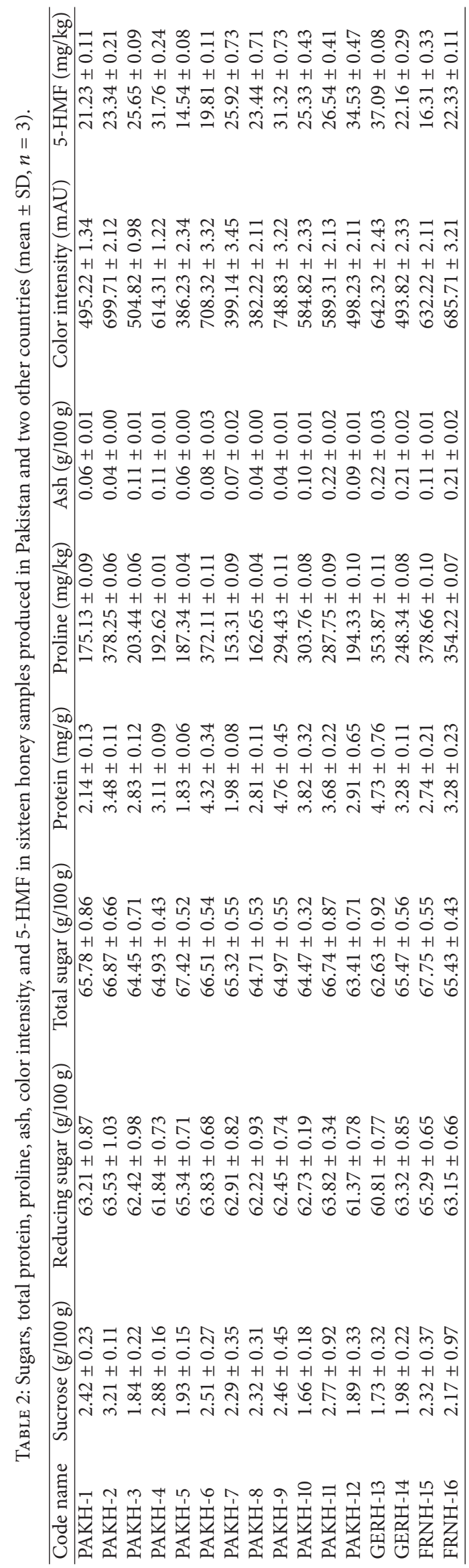




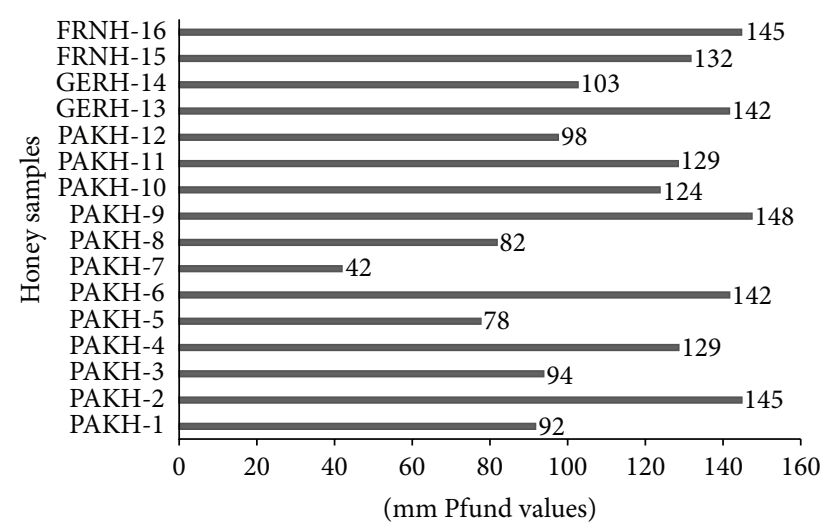

Figure 1: Color characteristics of local and exotic honey samples.

honey samples, nine samples were dark amber (124-148 mm Pfund), five samples were amber (92-103 mm Pfund), two samples were light amber (78 and $82 \mathrm{~mm}$ Pfund), and one sample was extra light amber ( $42 \mathrm{~mm}$ Pfund). The color characteristics are presented in Figure 1. The color intensities $\left(\mathrm{ABS}_{450}\right)$ of tested honey samples ranged between 382.22 and $748.83 \mathrm{mAU}$ (Table 2). The presence of pigments like carotenoids and flavonoids is related color of honey; dark color honey has large amount of these pigments and known to have highest oxidation potential which is proved in our study. Fresh honey contains trace amount of 5-HMF and this is essential parameter to indicate the purity of honey. The values of 5-HMF in tested honey samples are presented in Table 2; the data indicates that both local and exotic honey samples have 5 -HMF value ranging between 14.54 and $37.09 \mathrm{mg} / \mathrm{kg}$. These values are in compliance with standard requirement of $80 \mathrm{mg} / \mathrm{kg}[32,35]$. Since the label claimed of tested honey samples did not exceed the three-month storage, lower values of 5-HMF obtained in honey samples proved their claim of storage. Various factors are involved in higher values of 5HMF like prolonged storage or overheating (high temperature storage). 5-HMF values also depend on $\mathrm{pH}$, higher 5HMF results from acid-catalyzed (low $\mathrm{pH}$ ) dehydration of hexose sugars with particular more susceptibility of fructose. Overall, low values of 5-HMF in both local and exotic tested honey samples confirm their good quality.

3.2. Biochemical Analysis. Data in Table 2 indicated that the sucrose, reducing sugar, and total sugar contents ranged between 1.73 and $3.21 \%, 61.37$ and $65.34 \%$, and $62.63-$ $62.75 \%$, respectively. These obtained values are comparable with the results reported for sugars in honey samples in different countries like Nepal, Algeria, and Bangladesh [2, $25,36]$. Our data presented that reducing sugar results are as per recommendation of EC Directive 2001/110 ( $\geq 60 \mathrm{~g} / 100 \mathrm{~g}$ ) except the honeydew $(\geq 45 \mathrm{~g} / 100 \mathrm{~g})$. The results of sucrose are also in compliance with codex standard [34] that should be lower than 5\%. In our study, it is also indication of tested honey samples that are nonadulterated and high values of reducing sugar might be due to its nonconversion into 5HMF. The protein contents (Table 2) are found in range between 1.83 and $4.76 \mathrm{mg} / \mathrm{g}$ of honey. Different enzymes are responsible for protein in honey. These enzymes are added by bees during the ripening process of honey. The protein results for both monofloral and multifloral in this study are similar to results obtained for honey from Bangladesh, Malaysia, and Algeria. Generally protein contents ranged from 2 to $5 \mathrm{mg} / \mathrm{g}$ in honey $[2,10,22,25,26]$. The tested honey showed proline contents (Table 2) ranging between the 153.31 and $378.66 \mathrm{mg} / \mathrm{kg}$; there is significant difference between these two values. Carboxylic acid which is found most abundantly in honey is proline. Proline is produced by salivary secretion of honey bees during conversion of nectar into honey. Ripeness and sugar adulteration in honey are determined by amount of proline in honey. Generally proline content ranged between 202 and $680 \mathrm{mg} / \mathrm{kg}$ and minimum acceptable limit is $180 \mathrm{mg} / \mathrm{kg}$. The results showed that three samples have lower proline contents than the minimum acceptance level. Some author reported the proline content in wide range (343-1118 mg/kg). Antioxidant activity of honey also correlates with proline contents [22, 37]. In the present study, total phenolic contents (Table 3) were found in tested honey samples between the ranges of 501.42 and $611.62 \mathrm{mg} \mathrm{GAE} / \mathrm{kg}$ for dark amber color while 362.11$418.43 \mathrm{mg} \mathrm{GAE} / \mathrm{kg}$ were found for amber color. The phenolic contents of acacia (GERH-14) and jujube (PAKH-11) honey were found to be $595.53 \mathrm{mg} \mathrm{GAE} / \mathrm{kg}$ and $558.45 \mathrm{mg} \mathrm{GAE} / \mathrm{kg}$, respectively, comparable with honey found in Saudi Arabia and Yemen [37]. Quality and curative properties of honey can be determined from its total phenolic contents, antioxidant potential, and total phenolic contents which are in strong correlation with each other. Quality and quantity of phenolics are found in honey according to floral region. Dark color honeys have high phenolic contents than lighter ones and possess high antioxidation potential as indicated in our studies in Pakistani and exotic honey samples [10]. Low molecular weight phenolic compounds are flavonoids and these are vital components for antioxidant properties and aroma of honey. In present study, flavonoids contents in honey samples were determined on base of yellow color complex formation between the $\mathrm{Al}$ (III) and carbonyl oxygen and hydroxyl group present in flavonols and flavones. The flavonoids contents (Table 3) found in tested honey samples ranged between 11.83 and $57.66 \mathrm{mg} \mathrm{QE} / \mathrm{kg}$. The dark amber color honey has higher flavonoids contents and vice versa. The flavonoids found in both Pakistani and exotic honey samples are similar as reported earlier in Brazilian honey and lower than Burkina Fasan honey (17-83.5 mg QE/kg) by using this method [7, 38]. The ascorbic acid content (Table 3) was found between the ranges of 128.41 and $147.28 \mathrm{mg} / \mathrm{kg}$ of honey. The results obtained in tested honey samples of Pakistani and two other countries (Germany and France) are similar to results obtained in Bangladesh, Malaysia, Algeria, Portuguese, and India honey. In addition to phenolics, ascorbic acid present in honey also acts as antioxidant.

3.3. Antioxidant Activities. AEAC was determined by using the standard ascorbic acid calibration curve $\left(r^{2}=0.9968\right)$ in mg AEAC/100 g of honey. In data in Table 3, the AEAC values ranged from 17.11 to $31.76 \mathrm{mg} \mathrm{AEAC} / 100 \mathrm{~g}$ of honey. 
TABLE 3: Total phenolics, total flavonoids, ascorbic acid, AEAC, DPPH, and FRAP of sixteen honey samples produced in Pakistan and two other countries samples (mean $\pm \mathrm{SD}, n=3$ ).

\begin{tabular}{lcccccc}
\hline Code name & $\begin{array}{c}\text { Total phenolics } \\
(\mathrm{mg} \text { GAE/kg) }\end{array}$ & $\begin{array}{c}\text { Total flavonoids } \\
(\mathrm{mg} \text { QE/kg) }\end{array}$ & $\begin{array}{c}\text { Ascorbic acid }(\mathrm{mg} / \mathrm{kg}) \\
\text { AEAC }(\mathrm{mg} / 100 \mathrm{~g})\end{array}$ & $\begin{array}{c}\text { DPPH }(\% \text { Inhibition }) \\
(\mu \mathrm{M} \mathrm{Fe}(\mathrm{II}) / 100 \mathrm{~g})\end{array}$ \\
\hline PAKH-1 & $362.11 \pm 0.23$ & $45.87 \pm 0.41$ & $143.28 \pm 0.23$ & $17.11 \pm 0.13$ & $57.31 \pm 0.97$ & $454.34 \pm 1.13$ \\
PAKH-2 & $541.64 \pm 0.11$ & $57.66 \pm 0.43$ & $143.75 \pm 0.32$ & $22.64 \pm 0.23$ & $82.23 \pm 1.11$ & $646.34 \pm 1.11$ \\
PAKH-3 & $373.23 \pm 0.43$ & $47.86 \pm 0.22$ & $138.32 \pm 0.45$ & $25.05 \pm 0.13$ & $58.33 \pm 0.78$ & $465.74 \pm 1.03$ \\
PAKH-4 & $515.42 \pm 0.43$ & $51.32 \pm 0.45$ & $141.34 \pm 0.71$ & $31.76 \pm 0.24$ & $66.87 \pm 0.54$ & $502.02 \pm 0.91$ \\
PAKH-5 & $295.11 \pm 0.52$ & $28.92 \pm 0.64$ & $126.78 \pm 0.92$ & $17.04 \pm 0.28$ & $44.23 \pm 0.11$ & $255.33 \pm 1.52$ \\
PAKH-6 & $588.44 \pm 0.78$ & $49.87 \pm 0.53$ & $147.23 \pm 0.33$ & $19.31 \pm 0.15$ & $82.13 \pm 0.32$ & $595.33 \pm 1.18$ \\
PAKH-7 & $217.33 \pm 0.92$ & $11.83 \pm 0.65$ & $128.41 \pm 0.26$ & $25.42 \pm 0.13$ & $39.91 \pm 0.54$ & $238.21 \pm 0.12$ \\
PAKH-8 & $301.33 \pm 0.11$ & $18.32 \pm 0.71$ & $131.34 \pm 0.15$ & $22.94 \pm 0.11$ & $47.22 \pm 0.37$ & $311.82 \pm 0.41$ \\
PAKH-9 & $611.62 \pm 0.42$ & $52.15 \pm 0.57$ & $147.28 \pm 0.44$ & $30.12 \pm 0.23$ & $88.45 \pm 0.82$ & $672.02 \pm 1.42$ \\
PAKH-10 & $521.34 \pm 0.76$ & $48.32 \pm 0.78$ & $142.21 \pm 0.54$ & $26.03 \pm 0.81$ & $63.46 \pm 0.11$ & $511.77 \pm 1.16$ \\
PAKH-11 & $558.45 \pm 0.83$ & $42.11 \pm 0.34$ & $139.36 \pm 0.67$ & $26.66 \pm 0.71$ & $65.82 \pm 0.23$ & $548.15 \pm 1.13$ \\
PAKH-12 & $401.38 \pm 0.65$ & $38.23 \pm 0.31$ & $131.42 \pm 0.81$ & $32.53 \pm 0.87$ & $61.37 \pm 0.88$ & $491.33 \pm 1.47$ \\
GERH-13 & $595.53 \pm 0.51$ & $48.86 \pm 0.43$ & $145.58 \pm 0.43$ & $31.09 \pm 0.08$ & $81.81 \pm 0.43$ & $598.11 \pm 1.21$ \\
GERH-14 & $418.43 \pm 0.52$ & $39.83 \pm 0.44$ & $129.72 \pm 0.55$ & $22.18 \pm 0.09$ & $62.42 \pm 0.55$ & $498.77 \pm 1.12$ \\
FRNH-15 & $501.42 \pm 0.73$ & $56.21 \pm 0.32$ & $138.46 \pm 0.86$ & $18.31 \pm 0.48$ & $67.45 \pm 0.33$ & $521.02 \pm 0.91$ \\
FRNH-16 & $553.37 \pm 0.78$ & $53.11 \pm 0.34$ & $139.58 \pm 0.18$ & $23.36 \pm 0.81$ & $64.15 \pm 0.72$ & $553.88 \pm 1.18$ \\
\hline
\end{tabular}

These values are similar to already reported values for honey from different countries. The higher values have higher oxidation potential $[2,5,10,25,26,39]$. DPPH scavenging activity was determined by using $0.2 \mathrm{~g} / \mathrm{mL}$ concentration of each of honey sample. The percentage free radical inhibition (Table 3) of tested samples ranged between 39.91 and 88.45\%. Those honey samples having dark color had higher oxidation potential with higher percentage of inhibition of DPPH. The dark amber color honeys have percentage inhibition values $62.42-88.45 \%$ while amber color honeys have $57.31-61.37 \%$ inhibition. The lowest \% inhibition is achieved by the extra light amber honey (39.91\%). Free radical scavenging ability of various samples is determined by DPPH-stable nitrogen centered radical. Since antioxidant potential of honey is associated with phenolics and flavonoids contents, DPPH is frequently used for determining free radical scavenging ability. Higher the \% inhibition value superior will be the antioxidant activity of sample. The diseases with free radical origin can be treated with honey because it has ability to scavenge the free radical [2]. The FRAP values (Table 3) of tested honey samples (both monofloral and multifloral) ranged from 255.33 to $672.02 \mu \mathrm{M} \mathrm{Fe}$ (II)/100 g. These values are similar to that already reported in honey samples of different countries such as Slovenia, Cuba, Algeria, India, Malaysia, and Bangladesh. Again the honey samples having higher \% inhibition values of DPPH attributed to higher FRAP values and vice versa. Basically FRAP is reducing test which reflects the ability of substance to break the free radical chain reaction. Breaking the free radical chain reaction is indicator of antioxidant capacity. FRAP assay directly estimates the presence of reductant or antioxidant in samples which reduce the Fe (III) into Fe (II) [2].
3.4. Mineral Contents. The mineral contents (macro, micro, and trace) found in honey samples are presented in Table 4. The values obtained in our study are similar to results obtained in Brazilian and Romanian honey. The composition of mineral contents largely depends on the climatic conditions, geographical area, and floral sources. Other than the phenolics and flavonoids, copper and iron also have reducing or antioxidant properties [40].

3.5. Correlation between Antioxidant Properties, Biochemical Parameters, and Color Intensity. There is significant correlation (Table 5) found between the antioxidant properties, biochemical properties, and color intensity. A strong correlation was observed for flavonoids and phenolics with color intensity. As it was earlier reported in studies, the dark color honey contains higher phenolic and flavonoids contents and also our study on twelve Pakistani and four exotic honey samples proved the same result; that is, dark color honeys have strong antioxidant properties. The proline content is also a contributor in antioxidant properties of honey [31] which is in strong correlation ( $r=0.824$ and 0.727$)$ with flavonoids and phenolic contents. Phenolic contents have strong positive correlation with DPPH and FRAP $(r=0.914$ and 0.930$)$ as compared to flavonoids for same correlation $(r=0.799$ and $0.876)$. Another antioxidant ascorbic acid is in strong positive correlation with DPPH and FRAP $(r=0.832$ and 0.816$)$ but not more potent than flavonoids and phenolics. This correlation demonstrated the overall antioxidant properties of tested honey samples. Color pigments, phenolics, flavonoids, and proline are attributed to antioxidant properties of honey as expressed in correlation values. In conclusion, we investigated the physiochemical, biochemical, mineral contents, 
TABLE 4: Mineral contents in sixteen honey samples produced in Pakistan and two other countries samples.

\begin{tabular}{|c|c|c|c|c|c|c|c|c|c|c|c|c|c|}
\hline \multirow{2}{*}{ Code name } & \multicolumn{13}{|c|}{ Mineral contents $(\mathrm{mg} / \mathrm{kg})$} \\
\hline & $\mathrm{Ca}$ & $\mathrm{Cd}$ & Co & $\mathrm{Cr}$ & $\mathrm{Cu}$ & $\mathrm{Fe}$ & K & $\mathrm{Mg}$ & $\mathrm{Mn}$ & $\mathrm{Na}$ & $\mathrm{Ni}$ & $\mathrm{Pb}$ & $\mathrm{Zn}$ \\
\hline PAKH-1 & 57.23 & 0.91 & 0.015 & 0.021 & 0.21 & 19.11 & 400.2 & 54.54 & 0.73 & 150.2 & 0.11 & 0.075 & 2.14 \\
\hline PAKH-2 & 70.11 & 0.83 & 0.017 & 0.031 & 0.23 & 23.32 & 394.2 & 67.78 & 0.78 & 144.4 & 0.13 & 0.084 & 3.23 \\
\hline PAKH-3 & 53.65 & 0.76 & 0.009 & 0.012 & 0.26 & 21.35 & 432.5 & 43.25 & 0.76 & 122.8 & 0.16 & 0.065 & 2.32 \\
\hline PAKH-4 & 61.76 & 0.87 & 0.008 & 0.023 & 0.27 & 11.56 & 432.6 & 51.36 & 0.97 & 152.4 & 0.17 & 0.047 & 2.14 \\
\hline PAKH-5 & 76.11 & 0.92 & 0.007 & 0.034 & 0.22 & 16.75 & 456.7 & 44.45 & 0.83 & 166.6 & 0.21 & 0.032 & 3.19 \\
\hline PAKH-6 & 85.24 & 0.97 & 0.018 & 0.032 & 0.27 & 15.33 & 511.8 & 55.33 & 0.73 & 141.3 & 0.11 & 0.034 & 3.64 \\
\hline PAKH-7 & 72.22 & 0.83 & 0.019 & 0.034 & 0.23 & 12.32 & 345.9 & 72.02 & 0.83 & 145.4 & 0.25 & 0.025 & 3.11 \\
\hline PAKH-8 & 82.82 & 0.73 & 0.009 & 0.025 & 0.23 & 22.32 & 346.9 & 56.12 & 0.73 & 176.6 & 0.24 & 0.028 & 2.54 \\
\hline PAKH-9 & 72.32 & 0.78 & 0.007 & 0.026 & 0.28 & 22.72 & 445.4 & 56.32 & 0.78 & 155.6 & 0.17 & 0.029 & 2.32 \\
\hline PAKH-10 & 82.11 & 0.76 & 0.018 & 0.025 & 0.26 & 25.66 & 421.7 & 62.76 & 0.76 & 161.7 & 0.18 & 0.067 & 2.45 \\
\hline PAKH-11 & 52.93 & 0.92 & 0.015 & 0.024 & 0.22 & 34.33 & 441.8 & 55.87 & 0.83 & 181.5 & 0.18 & 0.078 & 2.67 \\
\hline PAKH-12 & 83.42 & 0.98 & 0.014 & 0.022 & 0.28 & 33.42 & 445.6 & 63.22 & 0.76 & 175.4 & 0.19 & 0.074 & 2.87 \\
\hline GERH-13 & 88.22 & 0.84 & 0.019 & 0.035 & 0.24 & 21.52 & 421.7 & 48.92 & 0.87 & 181.4 & 0.21 & 0.053 & 2.23 \\
\hline GERH-14 & 82.37 & 0.76 & 0.008 & 0.016 & 0.26 & 22.22 & 411.4 & 72.07 & 0.92 & 181.7 & 0.22 & 0.066 & 3.12 \\
\hline FRNH-15 & 74.48 & 0.87 & 0.009 & 0.018 & 0.27 & 14.43 & 398.8 & 54.18 & 0.83 & 168.5 & 0.25 & 0.046 & 2.18 \\
\hline FRNH-16 & 72.43 & 0.95 & 0.007 & 0.032 & 0.25 & 12.53 & 501.5 & 52.03 & 0.76 & 171.4 & 0.22 & 0.054 & 3.11 \\
\hline
\end{tabular}

TABLE 5: Correlation among biochemical parameters, antioxidant properties, and color intensity.

\begin{tabular}{|c|c|c|c|c|c|c|c|}
\hline & Flavonoids & Ascorbic acid & Protein & Proline & DPPH & FRAP & $\mathrm{ABS}_{450}$ \\
\hline Phenolics & $0.835^{* *}$ & $0.813^{* *}$ & $0.866^{* *}$ & $0.824^{* *}$ & $0.914^{* *}$ & $0.930^{* *}$ & $0.770^{* *}$ \\
\hline Flavonoids & & $0.768^{* *}$ & $0.548^{*}$ & $0.727^{* *}$ & $0.799^{* *}$ & $0.876^{* *}$ & $0.648^{* *}$ \\
\hline Ascorbic acid & & & $0.725^{* *}$ & $0.621^{*}$ & $0.832^{* *}$ & $0.816^{* *}$ & $0.859^{* *}$ \\
\hline Protein & & & & $0.665^{* *}$ & $0.869^{* *}$ & $0.821^{* *}$ & $0.657^{* *}$ \\
\hline Proline & & & & & $0.771^{* *}$ & $0.767^{* *}$ & $0.595^{*}$ \\
\hline DPPH & & & & & & $0.956^{* *}$ & $0.757^{* *}$ \\
\hline FRAP & & & & & & & $0.718^{* *}$ \\
\hline
\end{tabular}

${ }^{* *}$ Correlation is significant at $p<0.01$.

${ }^{*}$ Correlation is significant at $p<0.05$.

and oxidation potential of honey available in commercial market for first time in Pakistan. Both the monofloral (jujube and acacia) and multifloral honeys were tested. Tested honey samples have lower contents of 5-HMF which might be due to acidic $\mathrm{pH}$ and low moisture content which prevent its formation. Higher oxidation potential possessed by honey is indicated from their phenolics and flavonoids contents. Total sugar contents are found in range given by codex standard which is indication of nonadulterated honey. The mineral contents are also investigated because iron and copper also have antioxidant properties. Strong correlation was also found between the biochemical and antioxidant agents. Phenolics have most significant positive correlation with DPPH and FRAP. Overall both Pakistani and exotic honey samples have strong oxidation potential which can be used for treatment of free radical origin diseases.

\section{Conflict of Interests}

The authors declare that there is no conflict of interests regarding the publication of this paper.

\section{References}

[1] N. Gheldof, X.-H. Wang, and N. J. Engeseth, "Identification and quantification of antioxidant components of honeys from various floral sources," Journal of Agricultural and Food Chemistry, vol. 50, no. 21, pp. 5870-5877, 2002.

[2] M. I. Khalil, M. Moniruzzaman, L. Boukraâ et al., "Physicochemical and antioxidant properties of algerian honey," Molecules, vol. 17, no. 9, pp. 11199-11215, 2012.

[3] S. Saxena, S. Gautam, and A. Sharma, "Physical, biochemical and antioxidant properties of some Indian honeys," Food Chemistry, vol. 118, no. 2, pp. 391-397, 2010.

[4] J. W. White, "Composition of honey," in Honey. A Comprehensive Survey, pp. 157-206, William Heinemann, New York, NY, USA, 1975.

[5] Council Directive of the European Union, "Council directive 2001/110/EC of 20 December 2001 relating to honey," Official Journal of the European Communities, pp. 47-52, 2002.

[6] G. A. Nayik and V. Nanda, "Characterization of the volatile profile of unifloral honey from Kashmir Valley of India by using solid-phase microextraction and gas chromatographymass spectrometry," European Food Research and Technology, vol. 240, pp. 1091-1100, 2015. 
[7] J. Bertoncelj, U. Doberšek, M. Jamnik, and T. Golob, "Evaluation of the phenolic content, antioxidant activity and colour of Slovenian honey," Food Chemistry, vol. 105, no. 2, pp. 822-828, 2007.

[8] M. L. Al, D. Daniel, A. Moise, O. Bobis, L. Laslo, and S. Bogdanov, "Physico-chemical and bioactive properties of different floral origin honeys from Romania," Food Chemistry, vol. 112, no. 4, pp. 863-867, 2009.

[9] I. C. F. R. Ferreira, E. Aires, J. C. M. Barreira, and L. M. Estevinho, "Antioxidant activity of Portuguese honey samples: different contributions of the entire honey and phenolic extract," Food Chemistry, vol. 114, no. 4, pp. 1438-1443, 2009.

[10] A. Meda, C. E. Lamien, M. Romito, J. Millogo, and O. G. Nacoulma, "Determination of the total phenolic, flavonoid and proline contents in Burkina Fasan honey, as well as their radical scavenging activity," Food Chemistry, vol. 91, no. 3, pp. 571-577, 2005.

[11] J. M. Alvarez-Suarez, A. M. González- Paramás, C. SantosBuelga, and M. J. Battino, "Antioxidant characterization of native monofloral Cuban honeys," Journal of Agricultural and Food Chemistry, vol. 58, no. 17, pp. 9817-9824, 2010.

[12] M. I. Khalil, N. Alam, M. Moniruzzaman, S. A. Sulaiman, and S. H. Gan, "Phenolic acid composition and antioxidant properties of Malaysian honeys," Journal of Food Science, vol. 76, no. 6, pp. C921-C928, 2011.

[13] R. Socha, L. Juszczak, S. Pietrzyk, and T. Fortuna, "Antioxidant activity and phenolic composition of herbhoneys," Food Chemistry, vol. 113, no. 2, pp. 568-574, 2009.

[14] M. Subrahmanyam, "Topical application of honey in treatment of burns," British Journal of Surgery, vol. 78, no. 4, pp. 497-498, 1991.

[15] S. D. Ladas, D. N. Haritos, and S. A. Raptis, "Honey may have a laxative effect on normal subjects because of incomplete fructose absorption," The American Journal of Clinical Nutrition, vol. 62, no. 6, pp. 1212-1215, 1995.

[16] A. J. Tonks, R. A. Cooper, K. P. Jones, S. Blair, J. Parton, and A. Tonks, "Honey stimulates inflammatory cytokine production from monocytes," Cytokine, vol. 21, no. 5, pp. 242-247, 2003.

[17] N.-A. M. Nasir, A. S. Halim, K.-K. B. Singh, A. A. Dorai, and M.-N. M. Haneef, "Antibacterial properties of tualang honey and its effect in burn wound management: a comparative study," BMC Complementary and Alternative Medicine, vol. 10, article 31, 2010.

[18] S. Z. Hussein, K. M. Yusoff, S. Makpol, and Y. A. M. Yusof, "Antioxidant capacities and total phenolic contents increase with gamma irradiation in two types of Malaysian honey," Molecules, vol. 16, no. 8, pp. 6378-6395, 2011.

[19] C. Kandaswami and E. Middleton Jr., "Free radical scavenging and antioxidant activity of plant flavonoids," Advances in Experimental Medicine and Biology, vol. 366, pp. 351-376, 1994.

[20] J. M. Alvarez-Suarez, F. Giampieri, A. M. González-Paramás et al., "Phenolics from monofloral honeys protect human erythrocyte membranes against oxidative damage," Food and Chemical Toxicology, vol. 50, no. 5, pp. 1508-1516, 2012.

[21] M. Kassim, K. M. Yusoff, G. Ong, S. Sekaran, M. Y. B. M. Yusof, and M. Mansor, "Gelam honey inhibits lipopolysaccharideinduced endotoxemia in rats through the induction of heme oxygenase-1 and the inhibition of cytokines, nitric oxide, and high-mobility group protein B1," Fitoterapia, vol. 83, no. 6, pp. 1054-1059, 2012.
[22] M. Kassim, M. Mansor, N. Al-Abd, and K. M. Yusoff, "Gelam honey has a protective effect against lipopolysaccharide (LPS)induced organ failure," International Journal of Molecular Sciences, vol. 13, no. 5, pp. 6370-6381, 2012.

[23] S. Bogdanov, "Water content: comparison of refractometric methods with the Karl Fischer method," in Proceedings of the Annual Meeting of the International Honey Commission, Dijon, France, 1999.

[24] K. Nigussie, P. A. Subramanian, and G. Mebrahtu, "Physicochemical analysis of Tigray honey: an attempt to determine major quality markers of honey," Bulletin of the Chemical Society of Ethiopia, vol. 26, no. 1, pp. 127-133, 2012.

[25] A. Islam, I. Khalil, N. Islam et al., "Physicochemical and antioxidant properties of Bangladeshi honeys stored for more than one year," BMC Complementary and Alternative Medicine, vol. 12, article 177, 2012.

[26] M. Moniruzzaman, S. A. Sulaiman, M. I. Khalil, and S. H. Gan, "Evaluation of physicochemical and antioxidant properties of sourwood and other Malaysian honeys: a comparison with manuka honey," Chemistry Central Journal, vol. 7, article 138, 2013.

[27] L. D. O. Sant'Ana, A. B. Buarque Ferreira, M. C. A. Lorenzon, R. L. L. Berbara, and R. N. Castro, "Correlation of total phenolic and flavonoid contents of Brazilian honeys with colour and antioxidant capacity," International Journal of Food Properties, vol. 17, no. 1, pp. 65-76, 2014.

[28] O. H. Lowry, N. J. Rosebrough, A. L. Farr, and R. J. Randall, "Protein measurement with the Folin phenol reagent," The Journal of Biological Chemistry, vol. 193, no. 1, pp. 265-275, 1951.

[29] C. S. Ough, "Rapid determination of proline in grapes and wines," Journal of Food Science, vol. 34, no. 3, pp. 228-230, 1969.

[30] M. Ahmed, A. Khaleeq, and S. Ahmad, "Antioxidant and antifungal activity of aqueous and organic extracts of liquorice," World Applied Sciences Journal, vol. 30, no. 11, pp. 1664-1667, 2014.

[31] D. Y. Liao, Y. C. Chai, S. H. Wang, C. W. Chen, and M. S. Tsai, "Antioxidant activities and contents of flavonoids and phenolic acids of Talinum triangulare extracts and their immunomodulatory effects," Journal of Food and Drug Analysis, vol. 23, no. 2, pp. 294-302, 2015.

[32] M. A. Qadir, M. Ahmed, and S. Shahzad, "Determination of aluminium by electrothermal atomization atomic absorption spectrometry in serum to characterize hemodialysis toxicity," Analytical Letters, vol. 48, no. 1, pp. 147-153, 2015.

[33] M. A. Qadir, M. Ahmed, I. Haq, and S. Ahmed, "Improved limit of detection and quantitation development and validation procedure for quantification of zinc in insulin by atomic absorption spectrometry," Pakistan Journal of Pharmaceutical Sciences, vol. 28, pp. 875-879, 2015.

[34] Codex Alimentarius Commission Standards, "Revised Codex standard for honey," CODEX STAN 12-1981, Rev.1, 1987; Rev.2, 2001.

[35] A. Kayacier and S. Karaman, "Rheological and some physicochemical characteristics of selected Turkish honeys," Journal of Texture Studies, vol. 39, no. 1, pp. 17-27, 2008.

[36] M. J. Díez, C. Andrés, and A. Terrab, "Physicochemical parameters and pollen analysis of Moroccan honeydew honeys," International Journal of Food Science and Technology, vol. 39, no. 2, pp. 167-176, 2004.

[37] B. P. Neupane, K. P. Malla, A. Kaundinnyayana, P. Poudel, R. Thapa, and S. Shrestha, "Antioxidant properties of honey from 
different altitudes of Nepal Himalayas," Polish Journal of Food and Nutrition Sciences, vol. 65, no. 2, 2015.

[38] J. A. Pontis, L. A. M. A. da Costa, S. J. R. da Silva, and A. Flach, "Color, phenolic and flavonoid content, and antioxidant activity of honey from Roraima, Brazil," Food Science and Technology, vol. 34, no. 1, pp. 69-73, 2014.

[39] I. Jasicka-Misiak, A. Poliwoda, M. Dereń, and P. Kafarski, "Phenolic compounds and abscisic acid as potential markers for the floral origin of two Polish unifloral honeys," Food Chemistry, vol. 131, no. 4, pp. 1149-1156, 2012.

[40] M. Oroian, S. Amariei, A. Leahu, and G. Gutt, "Multi-element composition of honey as a suitable tool for its authenticity analysis," Polish Journal of Food and Nutrition Sciences, vol. 65, no. 2, pp. 93-100, 2015. 

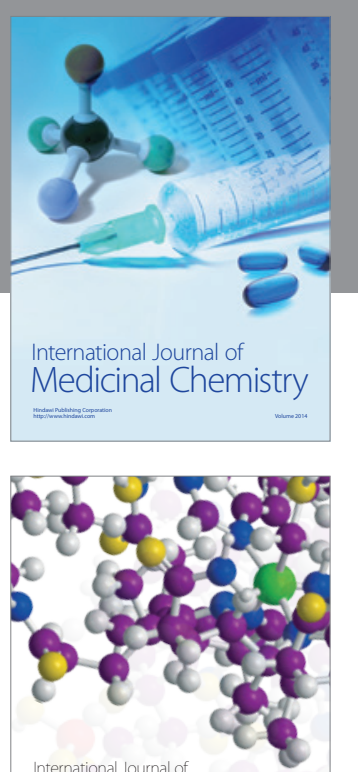

Carbohydrate Chemistry

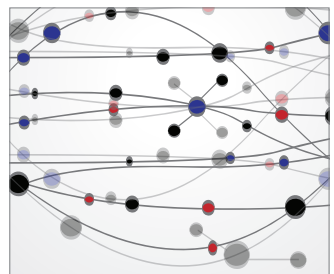

The Scientific World Journal
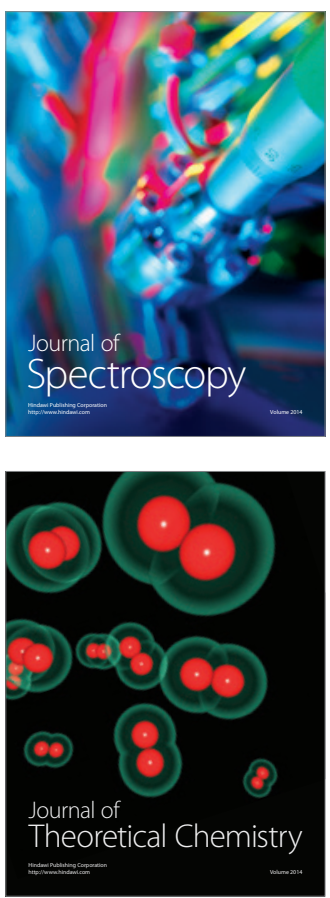
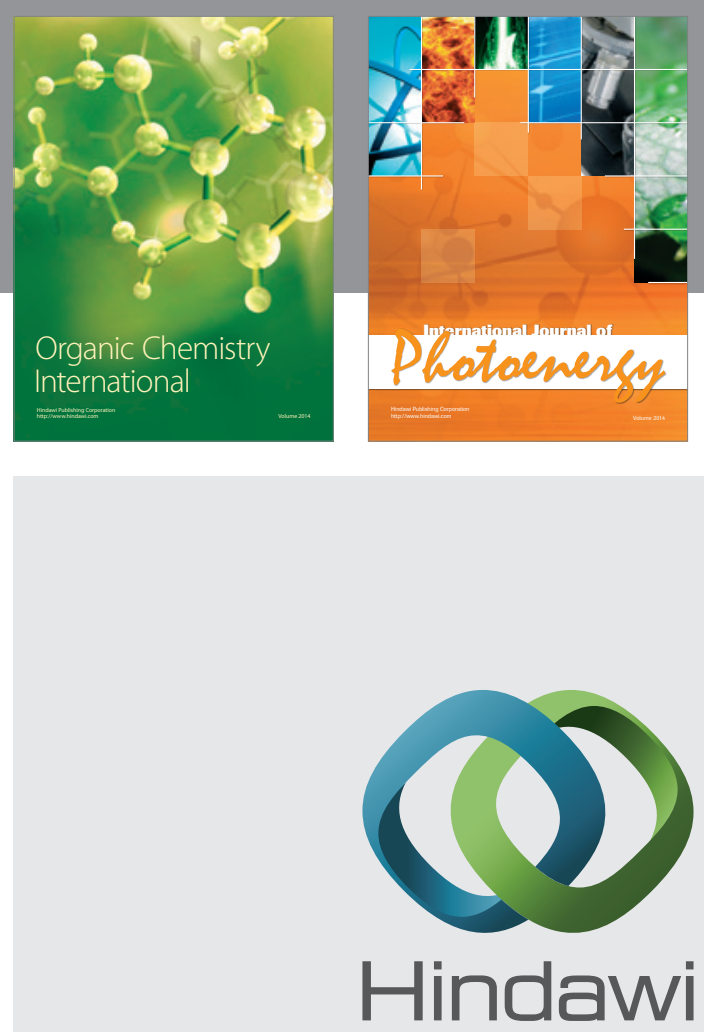

Submit your manuscripts at

http://www.hindawi.com

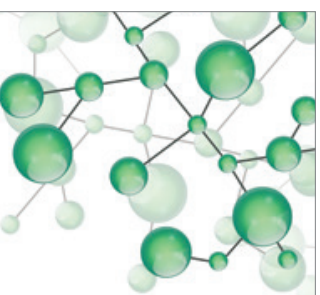

International Journal of

Inorganic Chemistry

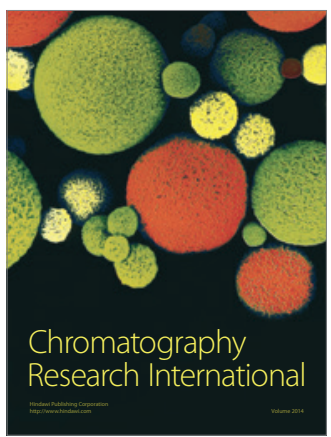

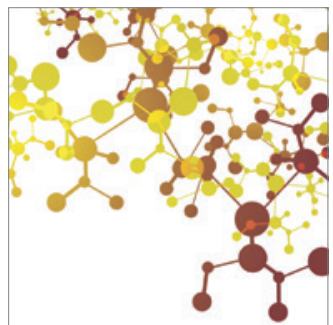

Applied Chemistry
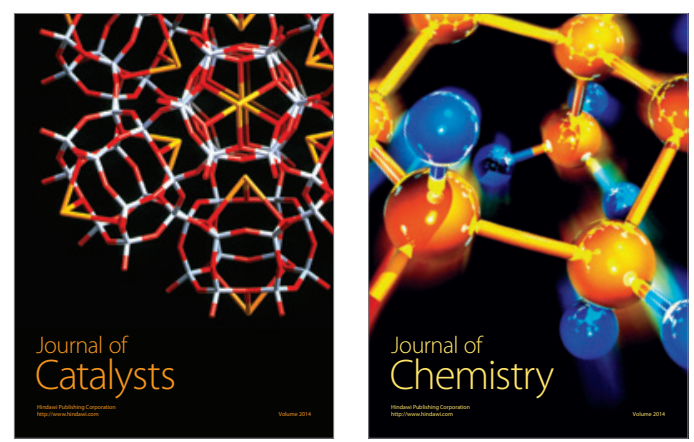
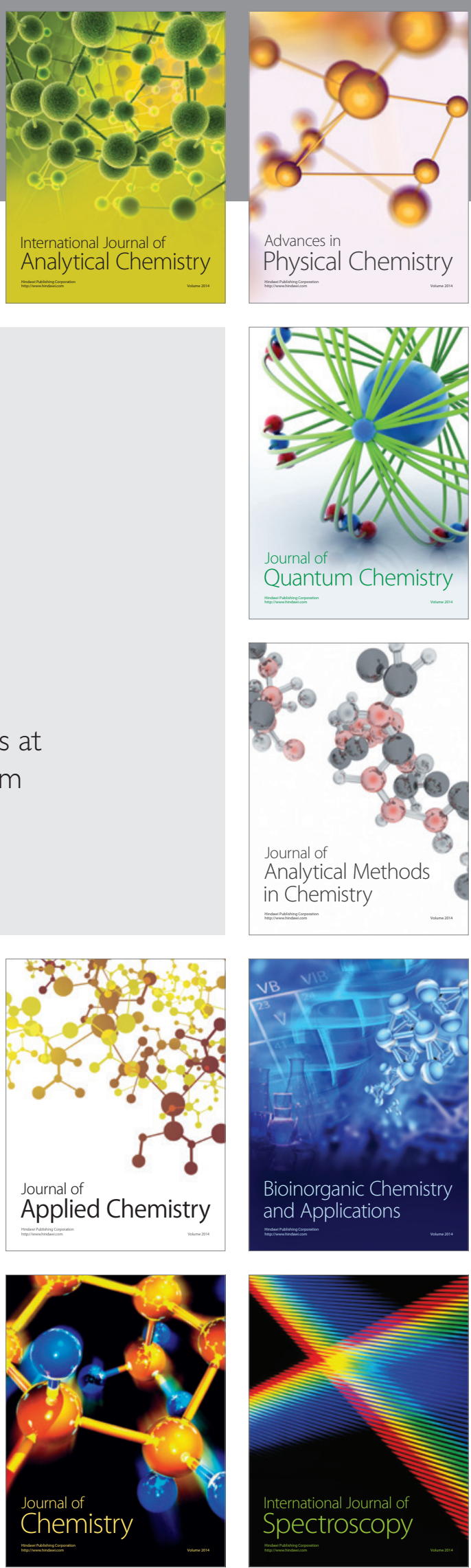